\title{
PERAN CITRA MEREK MEMEDIASI PENGARUH EWOM TERHADAP NIAT KONSUMEN MENGGUNAKAN GOPAY DI KOTA DENPASAR
}

\author{
Ni Putu Risma Giri Dewani ${ }^{1}$ \\ Ni Made Rastini ${ }^{2}$
}

\author{
Fakultas Ekonomi dan Bisnis Universitas Udayana, Bali, Indonesia. \\ email : imadewani06@gmail.com
}

\begin{abstract}
ABSTRAK
Niat beli dalam hal ini niat menggunakan adalah tahap di mana konsumen membuat keputusan terhadap beberapa merek, dan akhirnya memilih alternatif yang paling mereka sukai atau proses yang dialami oleh konsumen dalam memutuskan barang mana atau layanan untuk membeli berdasarkan berbagai pertimbangan. Penelitian ini dilakukan dengan tujuan untuk menjelaskan pengaruh $e W O M$ terhadap niat menggunakan melalui citra merek sebagai variabel mediasi. Penelitian ini dilakukan terhadap calon pengguna GoPay di Kota Denpasar dengan sampel penelitian sebanyak 130 orang, dimana teknik sampling yang digunakan adalah purposive sampling. Pengumpulan data menggunakan kuesioner yang disebarkan secara online melalui Google form. Teknik analisis yang digunakan adalah teknik analisis deskriptif dan teknik analisis path serta uji sobel. Hasil dari penelitian ini ditemukan adanya pengaruh positif dan signifikan $e W O M$ terhadap citra merek, pengaruh positif dan signifikan eWOM terhadap niat menggunakan, pengaruh positif dan signifikan citra merek terhadap niat menggunakan, dan citra merek memediasi secara positif dan signifikan pengaruh eWOM terhadap niat menggunakan. Implikasi penelitian ini diharapkan mampu memberikan masukan kepada pihak manajemen GoPay sehingga dapat merumuskan strategi yang tepat dalam rangka mempertahankan eksistensinya di masa yang akan datang.
\end{abstract}

Kata kunci: citra merek, eWOM, niat menggunakan.

\begin{abstract}
Purchase intention in this case the intention to use is the stage where consumers make decisions on several brands, and finally choose the alternative they like best or the process experienced by consumers in deciding which goods or services to buy based on various considerations. This research was conducted with the aim of explaining the effect of eWOM on intention to use through brand image as a mediating variable. This research was conducted on prospective GoPay users in Denpasar City with a research sample of 130 people, where the sampling technique used was purposive sampling. Collecting data using a questionnaire that is distributed online via Google form. The analysis technique used is descriptive analysis techniques and path analysis techniques and sobel test. The results of this study found that there is a positive and significant effect of eWOM on brand image, positive and significant influence of eWOM on intention to use, positive and significant influence of brand image on intention to use, and brand image positively and significantly mediates the effect of eWOM on intention to use.

The implication of this research is expected to be able to provide input to GoPay management so that it can formulate the right strategy in order to maintain its existence in the future.
\end{abstract}

Keywords: brand image, E-WOM, purchase intention. 


\section{PENDAHULUAN}

Globalisasi serta perkembangan teknologi telah mampu mengubah sikap serta gaya hidup orang-orang diseluruh dunia. Perkembangan teknologi yang semakin pesat ditandai dengan hadirnya internet. Internet telah menjadi bagian terpenting dari kehidupan yang mengubah cara berkomunikasi. Menurut Petralia et al. (2017) inovasi teknologi adalah kekuatan utama yang berkembang di balik pertumbuhan ekonomi, pengembangan industri, dan bangkitnya standar hidup. Berdasarkan informasi yang diperoleh dari Asosiasi Penyelenggara Jasa Internet Indonesia (APJII, 2019) dinyatakan bahwa jumlah penetrasi pengguna internet mencapai 171,17 juta pada tahun 2018 sebanyak 93,3 persen dari total pengguna mengakses internet setiap hari dengan menggunakan smartphone atau ponsel dimana Provinsi Bali dan Nusa Tenggara berkontribusi sebesar 5,2 persen dalam penetrasi pengguna internet tersebut. Menurut Kurnia (2019) Kota Denpasar sebagai Ibu Kota di Provinsi Bali merupakan kota dengan akses internet tertinggi yaitu sebanyak 68 persen dari total pengguna internet di Provinsi Bali.

Dengan perkembangan industri telekomunikasi nirkabel serta pertumbuhan internet di Indonesia, terutama di daerah Bali dapat menjadi peluang bagi para pebisnis untuk membuat inovasi terbaru. Inovasi baru ini dapat memenuhi kebutuhan serta standar gaya hidup manusia masa kini, dan memudahkan segala macam bentuk kegiatan manusia seperti metode pembayaran berbagai transaksi. Pertumbuhan layanan pembayaran seluler di Indonesia sangat dipengaruhi oleh penetrasi internet, terutama penggunaan internet melalui perangkat seluler. Mobile payment menjadi salah satu inovasi dalam metode pembayaran yang mulai banyak digunakan dijaman sekarang ini.

GoPay merupakan mobile payment yang telah berdiri sejak tahun 2016 yang dimiliki oleh perusahaan Gojek yang dapat diunduh melalui platform Android dan iOS. Dalam aktivitas pemasarannya perusahaan Gojek berusaha untuk menguatkan citra merek Gopay sehingga akan berdampak pada penyebaran informasi dari pengguna kepada calon pengguna lainnya. Berbagai upaya yang dilakukan untuk itu antara lain ; aplikasi GoPay mengakomodasi berbagai kebutuhan terkait dengan cashless dan mobile payment, adanya merchant ataupun retail yang bekerja sama dengan GoPay, dan GoPay selalu memberikan tawaran-tawaran menarik berupa diskon maupun cashback apabila melakukan transaksi pada retail offline menggunakan pembayaran melalui aplikasi GoPay. Dengan adanya kemudahankemudahan tersebut menyebabkan semakin banyak masyarakat berniat menggunakan mobile payment sebagai metode pembayaran dalam bertransaksi.

Niat beli atau dalam hal ini niat menggunakan dapat dikatakan sebagai proses setiap kali konsumen berniat untuk membeli produk apapun. Mereka membuat penelitian yang relevan dengan mengumpulkan informasi yang cukup berdasarkan pengalaman dan lingkungan mengenai produk atau jasa untuk selanjutnya membuat perbandingan dan mengevaluasi produk serta membuat penilaian tentang hal itu (Tariq et al., 2017). Menurut Kotler \& Armstrong (2017) niat beli adalah sesuatu yang timbul setelah menerima rangsangan dari produk yang dilihatnya, lalu muncul 
keinginan untuk membeli dan memilikinya. Berdasarkan pernyataan-pernyataan tersebut, dapat dikatakan bahwa penerimaan informasi akan mampu memberikan rangsangan kepada konsumen terhadap suatu produk. Informasi dapat diperoleh konsumen melalui media internet, seperti ulasan tentang suatu produk oleh konsumen lainnya yang dikenal dengan electronic word of mouth.

Electronic word of mouth yang selanjutnya ditulis eWOM dapat menjadi variabel yang penting didalam menentukan niat beli. Hal ini didukung dengan pernyataan Cahyono \& Gaffar Aziz (2016) yang mengungkapkan bahwa konsumen akan memanfaatkan eWOM untuk menilai suatu produk dan menjadikan eWOM sebagai salah satu faktor dari niat beli. Konsumen yang mengadopsi informasi eWOM akan cenderung memiliki niat pembelian pada sebuah produk (Erkan \& Evans, 2016). Hasil penelitian yang dilakukan oleh Saleem et al. (2015) menyatakan bahwa eWOM berpengaruh positif signifikan terhadap niat beli produk fashion di situs jejaring sosial. Sa'ait et al. (2016) menyatakan, eWOM memiliki hubungan positif dengan niat beli pelanggan. Hasil penelitian tersebut sejalan dengan Putri \& Amalia (2018) yang menyatakan konsumen cenderung mencari informasi tentang produk secara online untuk mendapatkan informasi produk tertentu yang akhirnya memunculkan niat untuk membeli produk tersebut. Akan tetapi, penelitian yang dilakukan oleh Alhidari (2015) menyatakan kemandirian tidak berpengaruh pada $e W O M$ di SNS atau niat membeli di SNS. Berdasarkan pernyataan tersebut, maka perlu adanya penambahan variabel yang dapat memperkuat $e W O M$ sebagai variabel yang dibutuhkan dalam niat beli. Citra merek dapat menjadi variabel yang berfungsi sebagai mediasi antara $e W O M$ dengan niat beli. Hal itu dikarenakan, citra merek dapat membantu pelanggan merakit informasi, merek diskriminasi, menciptakan perasaan positif, dan menciptakan penyebab untuk membeli (Mabkhot et al., 2017).

Menurut Kotler \& Armstrong (2017) menyatakan bahwa sekumpulan keyakinan terhadap suatu merek disebut citra merek. Pengertian citra merek juga diungkapkan oleh Tjiptono (2015:49) bahwa citra merek adalah deskripsi asosiasi dan keyakinan konsumen terhadap merek tertentu. Citra merek adalah salah satu faktor penentu keberhasilan strategi penjualan suatu perusahaan. Konsumen sering membandingkan dan memilih produk berdasarkan citra merek suatu produk yang lebih baik karena dirasa produk dengan reputasi merek yang kuat akan membuat konsumen merasa lebih nyaman dan reliabel (Adriyati \& Indriani, 2017).

Para pengusaha menjadikan niat beli sebagai alat ukur untuk kemungkinan sikap konsumen di masa yang akan datang. Niat konsumen dalam mengeksplor informasi mengenai suatu produk menjadi salah satu indikator yang dapat digunakan untuk mengukur niat beli (Ferdinand, 2014). Selain itu, adanya ketertarikan konsumen dalam menggunakan atau ingin memiliki suatu produk juga dapat dijadikan indikator pengukuran niat beli (Calvin \& Samuel, 2014).

Denpasar sebagai ibu kota Provinsi Bali yang memiliki penduduk dengan mobilitas, pengetahuan internet yang cukup tinggi, menempatkan posisi GoPay sebagai aplikasi yang cukup familiar bagi masyarakat. Hal ini dibuktikan oleh hasil pra survei yang dilakukan dengan menyebarkan kuisioner kepada responden yang belum pernah menggunakan aplikasi GoPay di kota Denpasar menunjukkan hasil seperti disajikan pada Tabel 1. berikut : 
Tabel 1.

Hasil Pra Survei Mengenai GoPay Kepada Responden yang Belum Pernah Menggunakan GoPay

\begin{tabular}{|c|c|c|c|c|}
\hline \multirow{2}{*}{ No } & \multirow{2}{*}{ Pertanyaan } & \multicolumn{2}{|c|}{$\frac{\text { Jumlah Responden }}{\text { (orang) }}$} & \\
\hline & & Ya & Tidak & \\
\hline 1 & $\begin{array}{l}\text { Apakah anda pernah mendengar } \\
\text { aplikasi GoPay? } \\
\text { (jika jawaban anda 'YA' } \\
\text { silahkan lanjut kepertanyaan } \\
\text { berikutnya) }\end{array}$ & 30 & 0 & \\
\hline 2 & $\begin{array}{l}\text { Apakah anda mengenal GoPay } \\
\text { dari media online, seperti } \\
\text { website atau blog? }\end{array}$ & 25 & 5 & \\
\hline 3 & $\begin{array}{l}\text { Apakah anda mengetahui nilai } \\
\text { positif dari aplikasi GoPay? }\end{array}$ & 25 & 5 & \\
\hline 4 & $\begin{array}{l}\text { Apakah anda berniat untuk men } \\
\text { aplikasi GoPay? }\end{array}$ & akan & 27 & 3 \\
\hline
\end{tabular}

Sumber: Hasil pra survei, 2020

Berdasarkan hasil pra survei tersebut, dapat diketahui bahwa GoPay telah dikenal oleh masyarakat Kota Denpasar sebagai aplikasi pembayaran online yang mana sebagian informasinya diperoleh melalui media online. Selain itu, 25 dari 30 responden memiliki kepekaan terhadap nilai positif dari merek GoPay itu sendiri sehingga membuat mereka berniat untuk menggunakan GoPay.

Hamidun \& Sanawiri (2018) mengungkapkan bahwa electronic word of mouth memiliki pengaruh yang signifikan terhadap variabel brand image. Hasil penelitian Adriyati \& Indriani (2017), Krisnawati \& Warmika (2020), Haikal et al. (2018) dan Mulyati et al. (2018) menunjukkan hasil yang sama dimana electronic word of mouth memiliki pengaruh yang positif signifikan terhadap variabel brand image.

$\mathrm{H}_{1}$ : eWOM memiliki pengaruh positif dan signifikan terhadap citra merek

Informasi yang terdapat pada $e W O M$ baik informasi positif maupun dengan negatif dapat mempengaruhi citra merek. Ketika suatu produk mendapat ulasan yang buruk, hal tersebut akan berdampak pada citra merek perusahaan tersebut. Persepsi masyarakat mengenai produk dengan ulasan buruk tentu akan mempengaruhi pertimbangan konsumen ketika akan membeli suatu produk.

Hamidun \& Sanawiri (2018) mengungkapkan bahwa variabel electronic word of mouth memiliki pengaruh yang signifikan terhadap variabel purchase intention. Hal yang sama juga diungkapkan oleh Haikal et al. (2018) dan Baber et al. (2016) menunjukkan hasil signifikan yang dimana bahwa eWOM secara 
signifikan masih memiliki pengaruh terhadap niat beli. Hasil serupa juga ditemukan oleh Saleem, et al. (2017) dan Sa'ait et al. (2016) yang menyatakan bahwa eWOM berpengaruh positif signifikan terhadap niat beli.

$\mathrm{H}_{2}$ :eWOM memiliki pengaruh positif dan signifikan terhadap

niat menggunakan

Krisnawati \& Warmika (2020) menunjukkan hasil bahwa brand image memiliki hubungan signifikan terhadap niat beli. Elseidi \& El-Baz (2016) dan Ardana \& Rastini (2018) mengungkapkan bahwa hubungan brand image pada purchase intention mendapat hasil yang positif dan signifikan. Penelitian dari Haikal et al. (2018) juga menunjukkan hasil citra merek memiliki hubungan yang signifikan terhadap niat beli. A.P \& Seminari (2020) juga menunjukkan brand image berpengaruh signifikan terhadap purchase intention.

$\mathrm{H}_{3}$ :Citra merek memiliki pengaruh positif dan signifikan terhadap

niat menggunakan

Krisnawati \& Warmika (2020) mengungkapkan dari hasil penelitian mereka eWOM dan brand image berpengaruh secara simultan dan signifikan terhadap purchase intention. Menurut Elseidi \& El-Baz (2016), Adriyati \& Indriani (2017)menyatakan bahwa eWOM berpengaruh positif terhadap niat beli dengan citra merek sebagai variabel mediasi. A.P \& Seminari (2020) dan Ardana \& Rastini (2018) juga menyatakan bahwa brand image berpengaruh signifikan memediasi electronic word of mouth terhadap purchase intention.

$\mathrm{H}_{4}$ :Citra merek mampu memediasi eWOM terhadap niat menggunakan

\section{METODE PENELITIAN}

Penelitian ini dilakukan pada calon pengguna aplikasi GoPay di Kota Denpasar. Alasan memilih lokasi ini, karena Kota Denpasar merupakan pusat kota dan pemerintahan serta perdagangan di Provinsi Bali yang terdiri dari beragam penduduk, mulai dari tingkat Pendidikan penduduk, tingkat edukasi serta tingkat keaktifan dan kepekaan kan suatu teknologi lebih baik dibandingkan dengan Kota/ Kabupaten lainnya di Provinsi Bali.Data primer yang digunakan pada penelitian berasal dari hasil penyebaran kuesioner pada responden. Populasi penelitian yaitu seluruh warga Kota Denpasar yang berniat untuk menggunakan aplikasi GoPay yang jumlahnya tidak dapat diketahui dengan pasti.

Teknik penentuan sampel dalam penelitian ini menggunakan teknik nonprobability sampling. Teknik nonprobability sampling yang dipilih adalah purposive sampling. Kriteria penentuan sampel adalah sebagai berikut responden berusia minimal 19 tahun, menempuh pendidikan terakhir minimal SMA, responden mengetahui aplikasi GoPay tapi belum pernah menggunakan aplikasi tersebut, dan berdomisili di Kota Denpasar.

Penulis memilih untuk menggunakan saran untuk melakukan analisis multivariate, jumlah indikator yang akan digunakan dalam penelitian ini adalah sebagai berikut : 13 indikator $\times 10=130$ responden. Metode pengumpulan data dalam penelitian ini dengan menyebar kuesioner secara online melalui Google form. Skala likert menjadi alat ukur pada pertanyaan-pertanyaan dalam kuesioner. 
Tabel 2.

Pengukuran Variabel Penelitian

\begin{tabular}{cll}
\hline $\begin{array}{c}\text { Variabel } \\
\text { Exogen }\end{array}$ & \multicolumn{1}{c}{ Indikator } \\
\hline$e W O M(\mathrm{X})$ & 1) & Komentar Positif (X.1) \\
& 2) & Rekomendasi Dari Pengguna Situs Jejaring Sosial (X.2) \\
& 3) & Informasi Variasi Produk/Jasa (X.3) \\
& 4) & Informasi kualitas produk/jasa (X.4) \\
& 5) & Informasi mengenai harga produk/jasa (X.5) \\
Endogen & 1) & Niat Eksploratif (Y.1) \\
Purchase Intention $(\mathrm{Y})$ & 2) & Ketertarikan Terhadap Produk (Y.2) \\
& 3) & Ketertarikan Untuk Mencoba Produk (Y.3) \\
Intervening & 4) & Berniat Untuk Menggunakan Produk (Y.4) \\
Citra Merek (M) & 1) & Citra positif (M.1) \\
& 2) & Dikenal masyarakat luas (M.2) \\
& 3) & Ciri khas yang berbeda (M.3) \\
& 4) & Favorable (M.4) \\
\hline
\end{tabular}

Sumber : (Goyette et al., 2010); (Ferdinand, 2014); (Calvin \& Samuel, 2014); Shimp (2014:40); Arista \& Astuti (2011))

Tabel 3.

Alternatif Jawaban Responden

\begin{tabular}{lll}
\hline Alternatif Jawaban Responden & Kode & Skor \\
\hline Sangat Setuju & SS & 5 \\
Setuju & S & 4 \\
Cukup Setuju & CS & 3 \\
Tidak Setuju & TS & 2 \\
Sangat Tidak Setuju & STS & 1 \\
\hline Sumber: Sugiyono, 2018 & &
\end{tabular}

\section{HASIL DAN PEMBAHASAN}

Responden dalam penelitian ini berjumlah 130 orang, sesuai dengan ukuran sampel yang digunakan. Responden penelitian digambarkan secara umum dengan menyajikan karakteristiknya dilihat dari umur, jenis kelamin, pekerjaan dan penghasilan yang disajikan pada Tabel 4 .

Tabel 4. menunjukkan bahwa sebagian besar responden yang belum pernah menggunakan aplikasi GoPay dalam penelitian ini didominasi oleh perempuan dengan persentase sebesar 61,54 persen. Berdasarkan umur responden data menunjukkan bahwa mayoritas responden berusia 19-22 tahun dengan persentase sebesar 75,38 persen dan memiliki jenjang pendidikan terakhir pada tingkat SMA/Sederajat. Hal ini disebabkan karena sebagian besar responden yang berpartisipasi dalam pengisian kuesioner adalah mahasiswa hal ini dapat dilihat dari persentase pekerjaan dengan pilihan pelajar/mahasiswa sebanyak 60 persen. Apabila ditinjau berdasarkan penghasilan menunjukkan bahwa responden yang belum pernah menggunakan aplikasi GoPay adalah responden yang memiliki penghasilan dari kurang dari lima ratus ribu rupiah yakni sebesar 30,77 persen. Hal ini memberikan informasi bahwa aplikasi GoPay dapat digunakan untuk 
penghasilan yang masih tergolong rendah sekalipun. relatif terjangkau, sehingga dapat dibeli oleh seluruh kalangan.

Tabel 4.

Karakteristik Responden

\begin{tabular}{|c|c|c|c|c|}
\hline No. & Variabel & Klasifikasi & $\begin{array}{l}\text { Jumlah } \\
\text { (orang) }\end{array}$ & $\begin{array}{c}\text { Persentase } \\
(\%)\end{array}$ \\
\hline \multirow[t]{2}{*}{1.} & \multirow[t]{2}{*}{ Jenis Kelamin } & Laki-laki & 50 & 38,46 \\
\hline & & Perempuan & 80 & 61,54 \\
\hline \multirow{7}{*}{2.} & \multirow[t]{3}{*}{ Jumlah } & & 130 & 100 \\
\hline & & 19-22 tahun & 98 & 75,38 \\
\hline & & 23-26 tahun & 17 & 13,08 \\
\hline & \multirow[t]{2}{*}{ Umur } & 27-30 tahun & 5 & 3,85 \\
\hline & & $>30$ tahun & 10 & 7,69 \\
\hline & \multirow[t]{3}{*}{ Jumlah } & & 130 & 100 \\
\hline & & SMA/Sederajat & 84 & 64,62 \\
\hline \multirow{4}{*}{3.} & & Diploma & 7 & 5,38 \\
\hline & $\begin{array}{l}\text { Tingkat } \\
\text { Pendidikan } \\
\text { Terakhir }\end{array}$ & Sarjana & 36 & 27,69 \\
\hline & & Pasca Sarjana & 3 & 2,31 \\
\hline & Jumlah & & 130 & 100 \\
\hline \multirow{8}{*}{4.} & \multirow{5}{*}{ Pekerjaan } & Pelajar/Mahasiswa & 78 & 60,00 \\
\hline & & $\begin{array}{l}\text { Pegawai Negeri } \\
\text { Sipil }\end{array}$ & 2 & 1,54 \\
\hline & & $\begin{array}{c}\text { Pegawai } \\
\text { Swasta/Pegawai } \\
\text { Kontrak }\end{array}$ & 26 & 20 \\
\hline & & Wiraswasta & 8 & 6,15 \\
\hline & & Lainnya & 16 & 12,31 \\
\hline & \multirow[t]{3}{*}{ Jumlah } & & 130 & 100 \\
\hline & & $<$ Rp.500.000,- & 40 & 30,77 \\
\hline & & $\begin{array}{l}\text { Rp.500.000-s/d } \\
\text { Rp.1.000.000,- }\end{array}$ & 37 & 28,46 \\
\hline 5. & $\begin{array}{l}\text { Penghasilan/Uang } \\
\text { Saku Setiap Bulan }\end{array}$ & $\begin{array}{l}\text { Rp.1.000.000-s/d } \\
\text { Rp.1.500.000,- }\end{array}$ & 11 & 8,46 \\
\hline
\end{tabular}




\begin{tabular}{|c|c|c|c|c|}
\hline No. & Variabel & Klasifikasi & $\begin{array}{l}\text { Jumlah } \\
\text { (orang) }\end{array}$ & $\begin{array}{r}\text { Persentase } \\
(\%)\end{array}$ \\
\hline & & $\begin{array}{c}\text { Rp.1.500.000-s/d } \\
\text { Rp.2.000.000,- }\end{array}$ & 13 & 10 \\
\hline & & $>$ Rp.2.000.000,- & 29 & 22,31 \\
\hline & Jumlah & & 130 & 100 \\
\hline
\end{tabular}

Sumber: Data diolah, 2020

Uji Validitas digunakan agar instrument penelitian dapat dinyatakan valid dan dapat digunakan maka syarat yang harus dipenuhi adalah skor total pertanyaan harus melebihi 0,30 . Instrument penelitian yang digunakan berhasi melebihi 0,30 sehingga semua butir pernyataan valid dan dapat digunakan.

Tabel 5.

Hasil Uji Validitas

\begin{tabular}{ccccc}
\hline Variabel & Indikator & $\begin{array}{c}\text { Koefisien } \\
\text { Korelasi }\end{array}$ & $\begin{array}{c}\text { Sig. (2- } \\
\text { tailed) }\end{array}$ & Keterangan \\
\hline \multirow{6}{*}{ eWOM (X) } & $\mathrm{X}_{1}$ & 0,731 & 0,000 & Valid \\
& $\mathrm{X}_{2}$ & 0,741 & 0,000 & Valid \\
& $\mathrm{X}_{3}$ & 0,769 & 0,000 & Valid \\
& $\mathrm{X}_{4}$ & 0,724 & 0,000 & Valid \\
& $\mathrm{X}_{5}$ & 0,646 & 0,000 & Valid \\
& $\mathrm{M}_{1}$ & 0,745 & 0,000 & Valid \\
Citra Merek (M) & $\mathrm{M}_{2}$ & 0,756 & 0,000 & Valid \\
& $\mathrm{M}_{3}$ & 0,798 & 0,000 & Valid \\
\multirow{5}{*}{ Niat Menggunakan } & $\mathrm{M}_{4}$ & 0,793 & 0,000 & Valid \\
(Y) & $\mathrm{Y}_{1}$ & 0,635 & 0,000 & Valid \\
& $\mathrm{Y}_{2}$ & 0,646 & 0,000 & Valid \\
& $\mathrm{Y}_{3}$ & 0,562 & 0,000 & Valid \\
& $\mathrm{Y}_{4}$ & 0,632 & 0,000 & Valid \\
\hline
\end{tabular}

Sumber :Data diolah, 2020

Hasil uji validitas pada Tabel 5. menunjukkan bahwa seluruh instrumen penelitian yang digunakan untuk mengukur variabel $e W O M$, citra merek dan niat menggunakan memiliki nilai koefisien korelasi dengan skor total seluruh item pernyataan lebih besar dari 0,30 dengan signifikansi kurang dari 0,05. Hal ini menunjukkan bahwa butir-butir pernyataan dalam instrumen penelitian tersebut valid dan layak digunakan sebagai instrument penelitian.

Setelah dilakukan uji reliabilitas. Dapat dilihat pada Tabel 6. instrument yang digunakan, hasil yang didapatkan adalah instrument penelitian reliabel dan dapat diandalkan. Hasil ini berdasarkan seluruh nilai Alpha Cronbach yang melebihi 0,60 dimana 0,60 merupakan batas yang telah ditentukan. Syarat agar instumen 
dikategorikan sebagai instrument yang reliabel adalah dengan nilai cronbach's alpha yang melebihi 0,60 .

Tabel 6.

Hasil Uji Reliabilitas

\begin{tabular}{clcc}
\hline No. & \multicolumn{1}{c}{ Variabel } & Cronbach's Alpha & Keterangan \\
\hline 1 & $e W O M(\mathrm{X})$ & 0,785 & Reliabel \\
2 & Citra merek $(\mathrm{M})$ & 0,806 & Reliabel \\
3 & Niat menggunakan $(\mathrm{Y})$ & 0,731 & Reliabel \\
\hline
\end{tabular}

Tabel 7.

Deskripsi Jawaban Responden Pada Variabel $e W O M$

\begin{tabular}{|c|c|c|c|c|c|c|c|c|}
\hline \multirow[t]{2}{*}{ Pernyataan } & \multicolumn{5}{|c|}{$\begin{array}{c}\text { Frekuensi Jawaban } \\
\text { Responden }\end{array}$} & \multirow{2}{*}{$\begin{array}{l}\text { Total } \\
\text { Skor }\end{array}$} & \multirow{2}{*}{$\begin{array}{c}\text { Rata- } \\
\text { rata }\end{array}$} & \multirow[t]{2}{*}{ Keterangan } \\
\hline & 1 & 2 & 3 & 4 & 5 & & & \\
\hline $\begin{array}{l}\text { Saya memperoleh berbagai } \\
\text { macam komentar positif } \\
\text { mengenai GoPay }\end{array}$ & 0 & 1 & 41 & 71 & 17 & 494 & 3,80 & Tinggi \\
\hline $\begin{array}{l}\text { Saya mendapatkan } \\
\text { rekomendasi untuk mencoba } \\
\text { GoPay }\end{array}$ & 0 & 0 & 36 & 78 & 16 & 500 & 3,85 & Tinggi \\
\hline $\begin{array}{l}\text { Saya memperoleh informasi } \\
\text { mengenai variasi yang } \\
\text { ditawarkan GoPay }\end{array}$ & 0 & 1 & 28 & 73 & 28 & 518 & 3,98 & Tinggi \\
\hline $\begin{array}{l}\text { Saya memperoleh informasi } \\
\text { bahwa GoPay memiliki }\end{array}$ & & & & & & & & \\
\hline $\begin{array}{l}\text { kualitas lebih baik } \\
\text { dibandingkan pesaing lainnya } \\
\text { yang sejenis }\end{array}$ & 0 & 0 & 32 & 80 & 18 & 506 & 3,89 & Tinggi \\
\hline $\begin{array}{l}\text { Saya memperoleh informasi } \\
\text { bahwa pembayaran melalui } \\
\text { GoPay lebih menguntungkan }\end{array}$ & 0 & 1 & 44 & 68 & 17 & 490 & 3,78 & Tinggi \\
\hline Rata-rata Var & b & & & & & 2509 & 3,86 & Tinggi \\
\hline
\end{tabular}

Sumber : Data diolah, 2019

Pada Tabel 7. frekuensi jawaban responden yang memperoleh penilaian tertinggi dari responden terdapat pada pernyataan "saya memperoleh informasi mengenai variasi yang ditawarkan GoPay", dengan nilai rata-rata sebesar 3,98. Sedangkan nilai terendah dari responden didapat dari pernyataan "saya memperoleh informasi bahwa pembayaran melalui GoPay lebih menguntungkan" dengan nilai rata-rata sebesar 3,78. Secara keseluruhan nilai rata-rata yang dihasilkan dari penilaian responden terhadap eWOM menunjukkan hasil yang tinggi yakni sebesar 3,86. Hal ini menunjukkan bahwa penilaian responden terhadap variabel $e W O M$ adalah baik.

4 pernyataan digunakan untuk mengukur variabel eksogen dari penelitian ini yaitu variabel citra merek. Hasil yang didapatkan dari penyebaran kuesioner kepada 
responden mengenai persepsi responden terhadap citra merek pada aplikasi GoPay disajikan pada Tabel 8 . berikut.

Tabel 8.

Deskripsi Jawaban Responden Pada Variabel Citra Merek

\begin{tabular}{|c|c|c|c|c|c|c|c|c|}
\hline \multirow[t]{2}{*}{ Pernyataan } & \multicolumn{5}{|c|}{$\begin{array}{c}\text { Frekuensi Jawaban } \\
\text { Responden }\end{array}$} & \multirow{2}{*}{$\begin{array}{l}\text { Total } \\
\text { Skor }\end{array}$} & \multirow{2}{*}{$\begin{array}{l}\text { Rata- } \\
\text { rata }\end{array}$} & \multirow[t]{2}{*}{ Keterangan } \\
\hline & 1 & 2 & 3 & 4 & 5 & & & \\
\hline $\begin{array}{l}\text { GoPay memilki image } \\
\text { positif dalam benak saya }\end{array}$ & 0 & 0 & 38 & 63 & 29 & 511 & 3,93 & Tinggi \\
\hline $\begin{array}{l}\text { GoPay memiliki ciri khas } \\
\text { yang membedakannya dari } \\
\text { pesaing lainnya yang sejenis }\end{array}$ & 0 & 0 & 18 & 83 & 29 & 531 & 4,08 & Tinggi \\
\hline $\begin{array}{l}\text { GoPay dikenal luas oleh } \\
\text { masyarakat khususnya di } \\
\text { Kota Denpasar }\end{array}$ & 0 & 1 & 28 & 76 & 24 & 510 & 3,92 & Tinggi \\
\hline $\begin{array}{l}\text { GoPay adalah merek yang } \\
\text { mudah diingat di benak saya }\end{array}$ & 0 & 2 & 35 & 68 & 25 & 506 & 3,89 & Tinggi \\
\hline \multicolumn{6}{|c|}{ Rata-rata Variabel Citra Merek } & 2058 & 3,96 & Tinggi \\
\hline
\end{tabular}

Sumber : Data diolah, 2020

Hasil perhitungan menunjukkan bahwa nilai responden yang paling tertinggi yaitu 4,08 dengan pernyataan "GoPay memiliki ciri khas yang membedakannya dari pesaing lainnya yang sejenis". Sedangkan nilai yang terendah yaitu 3,89 dengan pernyataan "GoPay dikenal luas oleh masyarakat khususnya di Kota Denpasar". Rata-rata keseluruhan persepsi responden mengenai variabel citra merek adalah sebesar 3,96. Nilai rata-rata yang dihasilkan termasuk pada kategori baik. Hal ini berarti secara keseluruhan responden merepresentasikan bahwa tingkat citra merek GoPay baik, sehingga sebagian besar responden memiliki pandangan bahwa GoPay memiliki citra yang baik di benak konsumen.

Variabel niat menggunakan diukur dengan menggunakan 4 item pernyataan yang berhubungan dengan niat menggunakan konsumen yang diberikan oleh pelanggan atau pengguna kepada aplikasi GoPay. Data yang ditunjukan Tabel 9. menampilkan proporsi jawaban responden, rata-rata jawaban, dan kriteria penilaian jawaban responden untuk masing-masing pernyataan pada variabel niat menggunakan.

Rata-rata yang dihasilkan dari seluruh persepsi responden terhadap niat menggunakan pada penelitian ini yaitu 3,95. Nilai ini termasuk pada kategori tinggi. Secara keseluruhan responden merepresentasikan bahwa sebagian besar responden memiliki niat untuk mencoba produk GoPay. Serta responden tertarik untuk mencari informasi tentang produk GoPay. Berdasarkan hasil deskripsi persepsi konsumen mengenai niat beli konsumen yang diukur dengan 4 indikator, cenderung menunjukkan nilai rata-rata tertinggi pada pernyataan "Saya berniat untuk menggunakan GoPay" dengan nilai sebesar 4,11. Hal ini menunjukkan 
bahwa secara keseluruhan responden berniat untuk mencoba layanan GoPay. Sedangkan nilai yang terendah yaitu 3,78 pada indikator mencari informasi " Saya berniat untuk mencari informasi mengenai GoPay".

Tabel 9.

Deskripsi Jawaban Responden Pada Variabel Niat Menggunakan

\begin{tabular}{|c|c|c|c|c|c|c|c|c|}
\hline \multirow[t]{2}{*}{ Pernyataan } & \multicolumn{5}{|c|}{$\begin{array}{c}\text { Frekuensi Jawaban } \\
\text { Responden }\end{array}$} & \multirow[t]{2}{*}{$\begin{array}{l}\text { Total } \\
\text { Skor }\end{array}$} & \multirow[t]{2}{*}{$\begin{array}{c}\text { Rata- } \\
\text { rata }\end{array}$} & \multirow[t]{2}{*}{$\begin{array}{c}\text { Ketera } \\
\text { ngan }\end{array}$} \\
\hline & 1 & 2 & 3 & 4 & 5 & & & \\
\hline $\begin{array}{l}\text { Saya berniat untuk mencari } \\
\text { informasi mengenai GoPay }\end{array}$ & 0 & 1 & 42 & 71 & 16 & 492 & 3,78 & Tinggi \\
\hline $\begin{array}{l}\text { Saya tertarik dengan GoPay } \\
\text { setelah mendapatkan } \\
\text { informasi mengenai produk } \\
\text { ini }\end{array}$ & 0 & 1 & 36 & 74 & 19 & 501 & 3,85 & Tinggi \\
\hline $\begin{array}{lr}\text { Saya } & \text { tertarik } \\
\text { mencoba } & \text { GoPay }\end{array}$ & 0 & 0 & 34 & 55 & 41 & 527 & 4,05 & Tinggi \\
\hline $\begin{array}{l}\text { Saya berniat untuk } \\
\text { menggunakan GoPay }\end{array}$ & 0 & 1 & 25 & 63 & 41 & 534 & 4,11 & Tinggi \\
\hline \multicolumn{6}{|c|}{ Rata-rata Variabel Niat Menggunakan } & 2054 & 3,95 & Tinggi \\
\hline
\end{tabular}

Berdasarkan hasil analisis jalur substruktur 1 seperti yang disajikan pada Tabel 10. maka persamaan strukturnya adalah sebagai berikut:

$\mathrm{M}=\beta_{1} \mathrm{X}+\mathrm{e}_{1} \ldots$
$\mathrm{M}=0,722 \mathrm{X}+\mathrm{e}_{1}$

Tabel 10.

Hasil Analisis Jalur Persamaan Regresi 1

\begin{tabular}{|c|c|c|c|c|c|}
\hline \multirow[t]{2}{*}{ Model } & \multicolumn{2}{|c|}{$\begin{array}{c}\text { Unstandardized } \\
\text { Coefficients }\end{array}$} & \multirow{2}{*}{$\begin{array}{c}\begin{array}{c}\text { Standardized } \\
\text { Coefficients }\end{array} \\
\text { Beta } \\
\end{array}$} & \multirow[b]{2}{*}{$\mathbf{t}$} & \multirow[b]{2}{*}{ Sig. } \\
\hline & B & $\begin{array}{l}\text { Std. } \\
\text { Error }\end{array}$ & & & \\
\hline 1 (Constant) & 3.486 & 1.058 & & 3.296 & .001 \\
\hline$e W O M$ & .642 & .054 & .722 & 11.792 & .000 \\
\hline R Square & .521 & & & & \\
\hline F Statistik & 139,060 & & & & \\
\hline Signifikansi Uji F & 0,000 & & & & \\
\hline
\end{tabular}

Sumber : Data diolah, 2020

Nilai koefisien regresi variabel $e W O M$ bernilai positif dengan nilai signifikansi uji t kurang dari 0,05 . Hal ini menunjukkan bahwa variabel eWOM memiliki pengaruh positif dan signifikan terhadap variabel citra merek. Besarnya pengaruh variabel bebas terhadap variabel terikat yang ditunjukkan oleh nilai determinasi total ( $\mathrm{R}$ Square) sebesar 0,521 mempunyai arti bahwa sebesar 52,1 persen variasi citra merek dipengaruhi oleh variasi eWOM, sedangkan sisanya sebesar 47,9 persen dijelaskan oleh faktor lain yang tidak dimasukkan ke dalam model. 
Berdasarkan hasil analisis jalur substruktur 2 seperti yang disajikan pada Tabel 11. maka persamaan strukturalnya adalah sebagai berikut:

$$
\begin{aligned}
& \mathrm{Y}=\beta_{2} \mathrm{X}+\beta_{3} \mathrm{M}+\mathrm{e}_{2} \ldots \ldots \ldots \ldots \\
& \mathrm{Y}=0,370 \mathrm{X}+0,254 \mathrm{M}+\varepsilon_{2}
\end{aligned}
$$

Tabel 11.

Hasil Analisis Jalur Persamaan Regresi 2

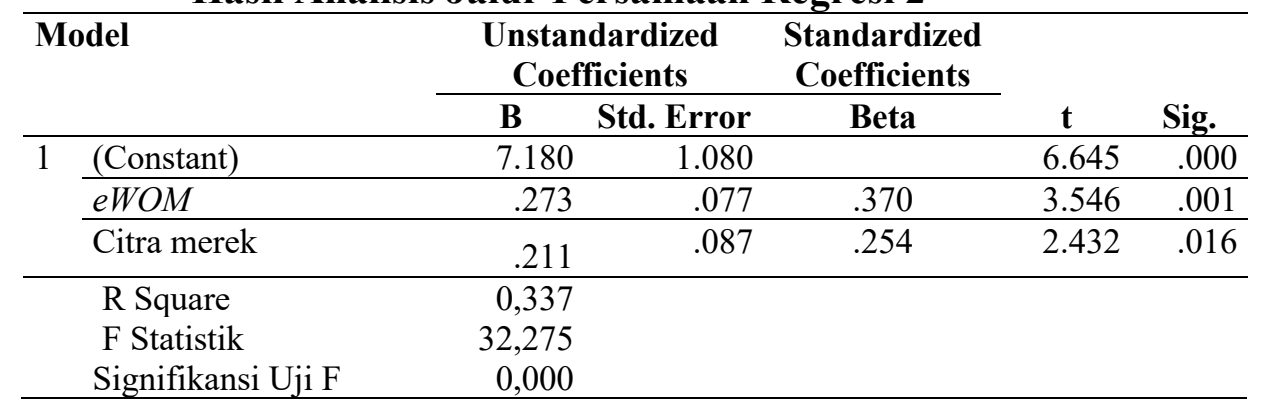

Sumber : Data diolah, 2019

Nilai koefisien regresi variabel eWOM bernilai positif dengan nilai signifikansi uji t kurang dari 0,05, sedangkan nilai koefisien regresi variabel citra merek bernilai positif dengan nilai signifikansi uji t lebih kecil dari 0,05 . Hal ini menunjukkan bahwa variabel $e W O M$ dan citra merek memiliki pengaruh positif dan signifikan terhadap variabel terikat. Besarnya pengaruh variabel bebas terhadap variabel terikat yang ditunjukkan oleh nilai determinasi total ( $\mathrm{R}$ Square) sebesar 0,337 mempunyai arti bahwa sebesar 33,7 persen variasi niat menggunakan dipengaruhi oleh variasi $e W O M$ dan citra merek, sedangkan sisanya sebesar 66,3 persen dijelaskan oleh faktor lain yang tidak dimasukkan ke dalam model.

Berdasarkan perhitungan pengaruh error (Pei), didapatkan hasil pengaruh error $\left(\mathrm{Pe}_{1}\right)$ sebesar 0,705 dan pengaruh error $\left(\mathrm{Pe}_{2}\right)$ sebesar 0,814 . Hasil koefisien determinasi total adalah 0,67 . Nilai determinasi total sebesar 0,67 mempunyai arti bahwa sebesar $67 \%$ variasi niat menggunakan dipengaruhi oleh variasi eWOM dan citra merek, sedangkan sisanya sebesar 33\% djelaskan oleh faktor lain yang tidak dimasukkan ke dalam model.

Tabel 12.

\begin{tabular}{cccc}
\multicolumn{4}{c}{$\begin{array}{c}\text { Pengaruh Langsung dan Pengaruh Tidak Langsung serta Pengaruh Total } \\
\text { eWOM (X), Citra Merek (M), dan Niat Menggunakan (Y) }\end{array}$} \\
\hline $\begin{array}{c}\text { Pengaruh } \\
\text { Variabel }\end{array}$ & $\begin{array}{c}\text { Pengaruh } \\
\text { Langsung }\end{array}$ & $\begin{array}{c}\text { Pengaruh Tidak Langsung Melalui } \\
\text { Citra Merek } \\
(\mathbf{M})(\boldsymbol{\beta} 1 \mathbf{x} \boldsymbol{\beta} 3)\end{array}$ & $\begin{array}{c}\text { Pengaruh } \\
\text { Total }\end{array}$ \\
\hline $\mathrm{X} \rightarrow \mathrm{M}$ & 0,722 & - & 0,722 \\
$\mathrm{X} \rightarrow \mathrm{Y}$ & 0,370 & 0,183 & 0,553 \\
$\mathrm{M} \rightarrow \mathrm{Y}$ & 0,254 & - & 0,254 \\
\hline
\end{tabular}

Sumber : Data primer diolah, 2020

Tabel 12. menunjukkan bahwa pengaruh langsung eWOM terhadap citra merek adalah sebesar 0,722 . Pengaruh langsung variabel $e W O M$ terhadap niat 
menggunakan sebesar 0,370 . Pengaruh langsung variabel citra merek terhadap niat menggunakan sebesar 0,254. Hal ini berarti bahwa variabel niat menggunakan lebih besar dipengaruhi oleh $e W O M$ daripada citra merek. Sedangkan pengaruh tidak langsung variabel $e W O M$ terhadap niat menggunakan melalui citra merek sebesar 0,183 . Jadi pengaruh total variabel eWOM terhadap niat menggunakan melalui citra merek adalah sebesar 0,553. Jadi dapat disimpulkan bahwa lebih besar nilai total pengaruh $e W O M$ terhadap niat menggunakan yang melalui citra merek, daripada pengaruh langsung $e W O M$ terhadap niat menggunakan tanpa melalui variabel citra merek.

Berdasarkan hasil pengujian pada Tabel 10. dan Tabel 11. menghasilkan koefisien $\mathrm{F} \leq 0,05$ dengan koefisien signifikan $\leq 0,05$ hal tersebut menunjukkan $e W O M$ dan citra merek berpengaruh secara simultan dan signifikan terhadap niat menggunakan.

Pengaruh $e W O M$ terhadap brand image. Hasil yang didapatkan dari analisis pengaruh $\mathrm{eWOM}$ terhadap citra merek adalah $\mathrm{H}_{1}$ diterima atau ditemukan adanya pengaruh yang positif antara hubungan $e W O M$ terhadap citra merek. hasil ini didapat dari nilai sig. $t$ yang dihasilkan dari analisis yaitu 0,000 . Nilai 0,000 memiliki nilai yang lebih kecil dari 0,05 . Hal ini menjadi dasar diterimanya $\mathrm{H}_{1}$ dan ditolaknya $\mathrm{H}_{0}$. Pengaruh yang ditemukan adalah pengaruh positif, hal ini dapat dilihat dari nilai koefisien beta yang bernilai positif yaitu 0,722 .

Pengaruh $e W O M$ terhadap niat menggunakan. Hasil yang didapatkan dari analisis pengarruh $e W O M$ terhadap niat menggunakan adalah $\mathrm{H}_{2}$ diterima atau ditemukan adanya pengaruh yang positif antara hubungan $e W O M$ terhadap niat menggunakan. hasil ini didapat dari nilai sig. t yang dihasilkan dari analisis yaitu 0,001 . Nilai 0,001 memiliki nilai yang lebih kecil dari 0,05 . Hal ini menjadi dasar diterimanya $\mathrm{H}_{2}$ dan ditolaknya $\mathrm{H}_{0}$. Pengaruh yang ditemukan adalah pengaruh positif, hal ini dapat dilihat dari nilai koefisien beta yang bernilai positif yaitu 0,370 .

Pengaruh citra merek terhadap niat menggunakan. Hasil yang didapatkan dari analisis pengaruh citra merek terhadap niat menggunakan adalah $\mathrm{H}_{3}$ diterima atau ditemukan adanya pengaruh yang positif antara citra merek terhadap niat menggunakan. hasil ini didapat dari nilai sig. $\mathrm{t}$ yang dihasilkan dari analisis yaitu 0,016. Nilai 0,016 memiliki nilai yang lebih kecil dari 0,05. Hal ini menjadi dasar diterimanya $\mathrm{H}_{3}$ dan ditolaknya $\mathrm{H}_{0}$. Pengaruh yang ditemukan adalah pengaruh positif, hal ini dapat dilihat dari nilai koefisien beta yang bernilai positif yaitu 0,254 .

Tabel 13.

\begin{tabular}{cccc}
$\begin{array}{c}\text { Pengaruh Langsung dan Pengaruh Tidak Langsung serta Pengaruh Total } \\
\text { eWOM (X), Citra Merek (M), dan Niat Menggunakan (Y) }\end{array}$ \\
\hline $\begin{array}{c}\text { Pengaruh } \\
\text { Variabel }\end{array}$ & $\begin{array}{c}\text { Pengaruh } \\
\text { Langsung }\end{array}$ & $\begin{array}{c}\text { Pengaruh Tidak Langsung Melalui } \\
\text { Citra Merek } \\
(\mathbf{M})(\boldsymbol{\beta} 1 \mathbf{x} \boldsymbol{\beta 3})\end{array}$ & $\begin{array}{c}\text { Pengaruh } \\
\text { Total }\end{array}$ \\
\hline $\mathrm{X} \rightarrow \mathrm{M}$ & 0,722 & - & 0,722 \\
$\mathrm{X} \rightarrow \mathrm{Y}$ & 0,370 & 0,183 & 0,553 \\
$\mathrm{M} \rightarrow \mathrm{Y}$ & 0,254 & - & 0,254 \\
\hline Sumber $:$ Data diolah, 2020 & &
\end{tabular}


Tabel 13. menunjukkan bahwa pengaruh langsung eWOM terhadap citra merek adalah sebesar 0,722. Pengaruh langsung variabel eWOM terhadap niat menggunakan sebesar 0,370 . Pengaruh langsung variabel citra merek terhadap niat menggunakan sebesar 0,254. Hal ini berarti bahwa variabel niat menggunakan lebih besar dipengaruhi oleh $e W O M$ daripada citra merek. Sedangkan pengaruh tidak langsung variabel $e W O M$ terhadap niat menggunakan melalui citra merek sebesar 0,183 . Jadi pengaruh total variabel eWOM terhadap niat menggunakan melalui citra merek adalah sebesar 0,553. Jadi dapat disimpulkan bahwa lebih besar total pengaruh $e W O M$ terhadap niat menggunakan yang melalui citra merek, daripada pengaruh langsung $e W O M$ terhadap niat menggunakan tanpa melalui variabel citra merek.

Tabel 14.

Hasil Uji Normalitas Struktur 1

\begin{tabular}{lc}
\hline & Unstandardized Residual \\
\hline $\mathrm{N}$ & 130 \\
Kolmogorov-Smirnov $Z$ & 0,103 \\
Asymp.Sig.(2-tailed) & 0,177 \\
\hline Sumber : Data diolah, 2020 &
\end{tabular}

Berdasarkan hasil uji normalitas pada struktur 1, dapat dilihat bahwa nilai Kolmogorov Sminarnov (K-S) sebesar 0,103, sedangkan nilai Asymp. Sig. (2tailed) sebesar 0,177. Hasil tersebut mengindikasikan bahwa model persamaan regresi tersebut berdistribusi normal karena nilai Asymp. Sig. (2-tailed) lebih besar dari nilai alpha 0,05 .

Berdasarkan hasil uji normalitas pada struktur 2, dapat dilihat pada Tabel 15. bahwa nilai Kolmogorov Sminarnov (K-S) sebesar 0,061, sedangkan nilai Asymp. Sig. (2-tailed) sebesar 0,200. Hasil tersebut mengindikasikan bahwa model persamaan regresi tersebut berdistribusi normal karena nilai Asymp. Sig. (2-tailed) lebih besar dari nilai alpha 0,05 .

Tabel 15.

Hasil Uji Normalitas Struktur 2

\begin{tabular}{lc}
\hline & Unstandardized Residual \\
\hline $\mathrm{N}$ & 130 \\
Kolmogorov-Smirnov $Z$ & 0,061 \\
Asymp.Sig.(2-tailed) & 0,200 \\
\hline Sumber : Data diolah, 2020 &
\end{tabular}

Untuk terbebas dari masalah multikolinearitas, nilai VIF yang harus dicapai adalah VIF yang bernilai lebih rendah dar 10. Nilai VIF ini berhasil dicapai oleh variabel E-WOM dan brand image sehingga menjadikan model regresi yang digunakan tidak memiliki masalah multikolinearitas. Untuk lebih jelasnya dapat dilihat pada Tabel 16 . 
Tabel 16.

Hasil Uji Multikolinearitas

\begin{tabular}{cccc}
\hline Struktur & Variabel & Tolerance & VIF \\
\hline Struktur 1 & $e W O M(\mathrm{X})$ & 1,000 & 1,000 \\
Struktur 2 & $e W O M(\mathrm{X})$ & 0,479 & 2,086 \\
& Citra Merek $(\mathrm{M})$ & 0,479 & 2,086 \\
\hline
\end{tabular}

Sumber : Data diolah, 2019

Variabel $e W O M$, dan citra merek pada persamaan regresi struktur 1 dan 2 memiliki nilai tolerance lebih besar dari $10 \%$ dan nilai VIF lebih kecil dari 10 yang berarti model persamaan regresi bebas dari multikolinearitas.

Tabel 17.

Hasil Uji Heteroskedastistas Struktur 1

\begin{tabular}{|c|c|c|c|c|c|c|}
\hline \multirow{2}{*}{\multicolumn{2}{|c|}{ Model }} & \multicolumn{2}{|c|}{$\begin{array}{c}\text { Unstandardized } \\
\text { Coefficients } \\
\end{array}$} & \multirow{2}{*}{$\begin{array}{c}\text { Standardized } \\
\text { Coefficients }\end{array}$} & \multirow[b]{2}{*}{$\mathbf{t}$} & \multirow[b]{2}{*}{ Sig. } \\
\hline & & B & Std. Error & & & \\
\hline 1 & (Constant) & 1.119 & .709 & & 1.577 & .117 \\
\hline & $e W O M$ & -.003 & .036 & -.007 & -.074 & .941 \\
\hline
\end{tabular}

Sumber : Data diolah, 2020

Pada Tabel 17. dapat dilihat bahwa nilai signifikansi dari variabel eWOM sebesar 0,117. Nilai tersebut lebih besar dari 0,05 yang berarti tidak terdapat pengaruh antara variabel bebas terhadap absolute residual. Dengan demikian, model yang dibuat tidak mengandung gejala heteroskedastisitas.

Tabel 18.

Hasil Uji Heteroskedastistas Struktur 2

\begin{tabular}{|c|c|c|c|c|c|}
\hline \multirow[t]{2}{*}{ Model } & \multicolumn{2}{|c|}{$\begin{array}{c}\text { Unstandardized } \\
\text { Coefficients }\end{array}$} & \multirow{2}{*}{$\begin{array}{c}\begin{array}{c}\text { Standardized } \\
\text { Coefficients }\end{array} \\
\text { Beta } \\
\end{array}$} & \multirow[b]{2}{*}{ 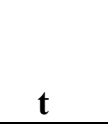 } & \multirow[b]{2}{*}{ Sig. } \\
\hline & B & Std. Error & & & \\
\hline (Constant) & 1.167 & .632 & & 1.872 & .064 \\
\hline$e W O M$ & -.066 & .044 & -.188 & -1.485 & .140 \\
\hline Citra merek & .079 & .050 & .199 & 1.573 & .118 \\
\hline
\end{tabular}

Sumber : Data diolah, 2020

Pada Tabel 18. dapat dilihat bahwa nilai signifikansi dari eWOM, dan citra merek, masing-masing sebesar 0,140 dan 0,118. Nilai tersebut lebih besar dari 0,05 yang berarti tidak terdapat pengaruh antara variabel bebas terhadap absolute residual. Dengan demikian, model yang dibuat tidak mengandung gejala heteroskedastisitas.

Uji sobel merupakan alat analisis untuk menguji signifikansi dari hubungan tidak langsung antara variabel independen dengan variabel dependen yang dimediasi oleh variabel mediator. Bila nilai kalkulasi $Z$ lebih besar dari 1,96 (dengan tingkat kepercayaan 95 persen), maka variabel mediator dinilai secara signifikan memediasi hubungan antara variabel terikat dan variabel bebas.

Untuk menguji signifikansi pengaruh tidak langsung maka nilai $\mathrm{z}$ dari koefisien ab dihitung dengan rumus sebagai berikut : 


$$
\begin{gathered}
S_{a b}=\sqrt{b^{2} s a^{2}+a^{2} s b^{2}+s a^{2} s b^{2}} \ldots \ldots \ldots \ldots \ldots \ldots \ldots(3) \\
S_{a b}=\sqrt{(0,254)^{2}(0,054)^{2}+(0,722)^{2}(0,087)^{2}+(0,054)^{2}(0,087)^{2}} \\
S_{a b}=0,068
\end{gathered}
$$

Untuk menguji signifikansi pengaruh tidak langsung maka menghitung nilai $\mathrm{z}$ dari koefisien ab dengan rumus sebagai berikut :

$$
\begin{aligned}
& Z=\frac{a b}{\sqrt{a^{2} S b^{2}+b^{2} S a^{2}+S a^{2} S b^{2}}} \ldots \ldots \ldots \ldots \ldots \\
& Z=\frac{(0,254)(0,722)}{0,063} \\
& Z=2,90 \text { dengan signifikansi } 0,000
\end{aligned}
$$

Hasil menunjukkan bahwa, Oleh karena Z hitung sebesar 2,90 $>1,96$. Artinya citra merek (M) merupakan variabel yang memediasi parsial dari eWOM (X) terhadap niat menggunakan (Y) pada aplikasi GoPay di kota Denpasar atau dengan kata lain $e W O M$ berpengaruh secara tidak langsung terhadap niat menggunakan melalui citra merek.

Hasil analisis dalam penelitian ini menunjukkan bahwa eWOM berpengaruh positif dan signifikan terhadap citra merek. Intensitas komunikasi eWOM yang tinggi mengenai suatu produk atau jasa akan mempengaruhi persepsi konsumen terhadap produk maupun jasa tersebut dan pada akhirnya persepsi konsumen akan membentuk citra merek dari produk tersebut. Berdasarkan hasil penelitian tersebut membuktikan bahwa semakin baik atau positif ulasan yang diberikan para pengguna maka citra merek yang dihasilkan aplikasi GoPay juga akan semakin baik sehingga dapat menambah nilai positif perusahaan itu sendiri. Hal ini sejalan dengan penelitian Hamidun \& Sanawiri (2018) mengungkapkan bahwa electronic word of mouth memiliki pengaruh yang signifikan terhadap variabel brand image. Hasil penelitian Adriyati \& Indriani (2017), Krisnawati \& Warmika (2020), Haikal et al. (2018) dan Mulyati et al. (2018) menunjukkan hasil yang sama dimana electronic word of mouth memiliki pengaruh yang positif signifikan terhadap variabel brand image. Sehingga, dapat dikatakan bahwa komunikasi eWOM dibentuk melalui tinjauan / rekomendasi yang sesuai dari mereka yang memiliki pengalaman sebelumnya tentang produk atau merek yang dapat mempengaruhi penilaian seseorang terhadap merek tersebut.

Hasil analisis menunjukkan bahwa $e W O M$ berpengaruh positif dan signifikan terhadap niat menggunakan. Hal ini memiliki makna bahwa semakin baik atau positif ulasan yang diberikan mengenai GoPay kepada para pengguna maka niat pengguna untuk menggunakan akan semakin tinggi pula. Begitu pula sebaliknya, apabila ulasan mengenai GoPay bersifat negatif akan semakin rendah pula niat pengguna untuk menggunakan aplikasi GoPay tersebut.

Hasil analisis dalam penelitian ini juga menunjukkan bahwa citra merek berpengaruh positif dan signifikan terhadap niat menggunakan. Hasil tersebut memperlihatkan bahwa Citra merek dari GoPay dapat memberikan kontribusi dalam membentuk niat beli konsumen. Semakin baik citra yang dimiliki oleh GoPay maka kontribusi dalam memikat niat konsumen dalam menggunakan 
aplikasi GoPay juga akan mudah tercapai. Hasil ini sejalan dengan Adriyati \& Indriani (2017) yang menyatakan bahwa konsumen sering membandingkan dan memilih produk berdasarkan citra merek suatu produk yang lebih baik karena dirasa produk dengan reputasi merek yang kuat akan membuat konsumen merasa lebih nyaman dan reliabel. Penelitian ini sejalan dengan hasil dari Krisnawati \& Warmika (2020) yang menunjukkan hasil bahwa brand image memiliki hubungan signifikan terhadap niat beli. Elseidi \& El-Baz (2016), Haikal et al. (2018) dan A.P \& Seminari (2020) mengungkapkan bahwa hubungan brand image pada purchase intention mendapat hasil yang positif dan signifikan.

Citra merek dan $e W O M$ merupakan faktor penting bagi konsumen untuk memutuskan akan menggunakan aplikasi GoPay atau tidak. Apabila eWOM yang diberikan konsumen kepada GoPay bersifat positif, maka akan mampu membentuk citra merek yang baik pula bagi konsumen, sehingga akan mampu meningkatkan niat konsumen untuk menggunakan layanan GoPay. Berdasarkan hasil uji Sobel, ditemukan pengaruh yang positif antara variabel eWOM terhadap niat menggunakan melalui variabel citra merek. Informasi, rekomendasi serta ajakan yang muncul melalui media sosial/online akan berpengaruh terhadap citra suatu produk di benak konsumen sehingga konsumen memilih untuk membeli atau menggunakan GoPay mobile payment atau memilih untuk tidak menggunakannya. Hasil penelitian ini konsisten dengan Krisnawati \& Warmika (2020) yang memberikan hasil bahwa eWOM dan brand image berpengaruh secara simultan dan signifikan terhadap purchase intention. Menurut Elseidi \& El-Baz (2016), Adriyati \& Indriani (2017) menyatakan bahwa eWOM berpengaruh positif terhadap niat beli dengan citra merek sebagai variabel mediasi. A.P \& Seminari (2020) juga menyatakan bahwa brand image berpengaruh signifikan memediasi electronic word of mouth terhadap purchase intention.

Penelitian ini memperkuat penelitian-penelitian sebelumnya dalam memperjelas pengaruh variabel $\mathrm{eWOM}$ terhadap niat menggunakan yang dimediasi oleh citra merek. Hasil penelitian ini menunjukkan bahwa semakin banyak informasi - informasi positif yang disebarkan melalui media online maka semakin tinggi citra merek GoPay di benak konsumen yang pada akhirnya akan meningkatkan niat untuk menggunakan GoPay.

Implikasi praktis penelitian ini menunjukkan secara keseluruhan konsumen yang belum pernah menggunakan GoPay menilai bahwa ulasan-ulasan yang ditunjukkan kepada GoPay secara online memiliki sifat yang positif sehingga memunculkan citra merek yang positif pula. variasi dan kualitas yang diberikan GoPay perlu dipertahankan agar tetap mendapat penilaian yang baik dari konsumen. Hasil jawaban responden juga menunjukkan secara keseluruhan konsumen yang belum pernah menggunakan aplikasi GoPay memiliki niat untuk menggunakan aplikasi tersebut dikarenakan ulasan yang positif yang didapat serta citra merek yang diberikan.

\section{SIMPULAN}

Berdasarkan hasil pembahasan penelitian yang telah dilakukan, maka dapat disimpulkan bahwa : 
eWOM berpengaruh positif dan signfikan terhadap citra merek. Hal ini memiliki makna bahwa semakin positif atau baik ulasan yang berikan maka akan semakin baik pula citra yang dihasilkan oleh GoPay.

eWOM berpengaruh positif dan signfikan terhadap niat menggunakan. Hal ini memiliki makna bahwa semakin positif atau baik ulasan yang diberikan konsumen kepada GoPay, maka semakin tinggi pula niat konsumen untuk menggunakan jasa layanan GoPay.

Citra merek berpengaruh positif dan signifikan terhadap niat menggunakan. Hal ini memiliki makna bahwa semakin baik citra yang dihasilkan oleh GoPay maka niat konsumen untuk menggunakan aplikasi GoPay dapat meningkat.

Citra merek secara positif dan signifikan memediasi pengaruh eWOM terhadap niat menggunakan. Hal ini memiliki makna bahwa citra merek memainkan peran penting untuk mempengaruhi persepsi pelanggan pada eWOM dan niat menggunakan. Informasi, rekomendasi serta ajakan yang muncul melalui media sosial/onlineakan berpengaruh terhadap citra merek suatu produk di benak konsumen sehingga konsumen memilih untuk membeli atau menggunakan GoPay mobile payment atau memilih untuk tidak menggunakannya.

\section{REFERENSI}

A.P, D. A. P., \& Seminari, N. K. (2020). Pengaruh Brand Image Dalam Memediasi Electronic Word Of Mouthterhadap Purchase Intentionpada Pengguna Traveloka. Journal of Home Economics of Japan, 9(1), 139-159. https://doi.org/10.11428/jhej1987.42.189

Adriyati, R., \& Indriani, F. (2017). Pengaruh Electronic Word of Mouth terhadap Citra Merek dan Minat Beli pada Produk Kosmetik Wardah. Diponegoro Journal of Management.

Alhidari, A., Iyer, P., \& Paswan, A. (2015). Personal level antecedents of eWOM and purchase intention, on social networking sites. CUSTOMER BEHAVIOUR, 14(2), 107-125. Retrieved from https://scihub.do/https://doi.org/10.1362/147539215X14373846805707

Ardana, Y. A., \& Rastini, N. M. (2018). Peran Citra Merek Memediasi Pengaruh E-Wom Terhadap Minat Beli Smartphone Samsung Di Kota Denpasar. EJurnal Manajemen Universitas Udayana, 7(11), 5901. https://doi.org/10.24843/ejmunud.2018.v07.i11.p04

Baber, A., Thurasamy, R., Malik, M. I., Sadiq, B., Islam, S., \& Sajjad, M. (2016). Online word-of-mouth antecedents, attitude and intention-to-purchase electronic products in Pakistan. Telematics and Informatics, 33(2), 388-400. https://doi.org/10.1016/j.tele.2015.09.004

Cahyono, E. K., \& Gaffar Aziz, A. K. (2016). Makro, Jurnal Manajemen \& Kewirausahaan, Vol. 1 No. 2| November 2016. 1(2). Retrieved from https://core.ac.uk/download/pdf/229038882.pdf

Calvin, \& Samuel, H. (2014). Analisis Pengaruh Iklan, Kepercayaan Merek, dan Citra Merek Terhadap Minat Beli Konsumen. Jurnal Manajemen Pemasaran 
Petra, 2(1).

Elseidi, R. I., \& El-Baz, D. (2016). Electronic Word Of Mouth Effects On Consumers Brand Attitudes, Brand Image And Purchase Intention: An Empirical Study In Egypt. The Bussines and Management Review, 7(5), 268276.

Erkan, I., \& Evans, C. (2016). The influence of eWOM in social media on consumers' purchase intentions: An extended approach to information adoption. Computers in Human Behavior, 61, 47-55. https://doi.org/10.1016/j.chb.2016.03.003

Ferdinand, A. (2002). Structural Equation Modelling dalam Penelitian Manajemen, Aplikasi Model-model Rumit dalam Penelitian untuk Tesis Magister dan Disertasi Doktor. Semarang: Universitas Diponegoro.

Haikal, R., Siti Dyah Handayani, \& Nuryakin. (2018). ISSN No : 2349-5677 The Influence Of Electronic Word Of Mouth On Brand Image And ISSN No : 23495677. (4), 22-29.

Hamidun, M. A., \& Sanawiri, B. (2018). Pengaruh Electronic Word of Mouth Terhadap Purchase Intention Melalui Brand Image (Studi Pada Followers Akun Instagram @Ouvalresearch). Jurnal Administrasi Bisnis (JAB),61(2), 61-68. Retrieved from http://administrasibisnis.studentjournal.ub.ac.id/index.php/jab/article/viewFil $\mathrm{e} / 2573 / 2967$

Kotler, P., \& Armstrong, G. (2017). Prinsip-Prinsip Pemasaran (12 jilid 1). Jakarta: Erlangga.

Krisnawati, N. W., \& Warmika, I. G. K. (2020). Peran Brand Image Memediasi Pengaruh E-Wom Terhadap Niat Konsumen Menggunakan Ovo Mobile Payment. E-Jurnal Manajemen Universitas Udayana. https://doi.org/10.24843/ejmunud.2020.v09.i01.p05

Kurnia, L. (2019). Penetrasi Internet di Bali Paling Tinggi.

Mabkhot, H. A., Hasnizam, \& Salleh, S. M. (2017). The influence of brand image and brand personality on brand loyalty, mediating by brand trust: An empirical study. Jurnal Pengurusan, 50, 71-82.

Mulyati, Y., Haryeni, \& Masruri. (2018). Pengaruh Electronic Word Of Mouth Terhadap Citra Destinasi Serta Dampaknya Pada Minat Dan Keputusan Berkunjung Wisatawan Domestik Pada Destinasi Wisata Kota Bukit Tinggi. Jurnal Ekonomi \& Bisnis Dharma Andalas, 20(1), 168-187.

Petralia, S., Balland, P. A., \& Morrison, A. (2017). Climbing the ladder of technological development. Research Policy. https://doi.org/10.1016/j.respol.2017.03.012

Putri, S. R., \& Amalia, R. (2018). Pengaruh E-WOM Terhadap Citra Perusahaan Dan Dampaknya Terhadap Niat Beli Konsumen Pada Situs Online Shopee . Id. Jurnal Ilmiah Mahasiswa EKonomi Manajemen, 3(2), 75-84. 
Sa'ait, N., Kanyan, A., \& Nazrin, M. F. (2016). The Effect of E-WOM on Customer Purchase Intention. International Academic Research Journal of Social Science.

Saleem, Anum \& Ellahi, A. (2017). Influence of electronic word of mouth on purchase intention of fashion products in social networking websites. Pakistan Journal of Commerce and Social Sciences (PJCSS), 11(2), 597-622. Retrieved from https://www.econstor.eu/bitstream/10419/188307/1/pjcss384.pdf

Saleem, B. A., Ghafar, A., Ibrahim, M., Yousuf, M., \& Ahmed, N. (2015). Product Perceived Quality and Purchase Intention withConsumer Satisfaction. Global Journal of Management and Business Research: E Marketing.

Tariq, M., Tanveer, A., Abrar, M., \& Iqbal, A. (2017). EWOM \& Brand Awareness Impact on Consumer Purchase Intention: Mediating Role Of Brand Image. Pakistan Administrative Review.

Tjiptono, F. (2015). Strategi Pemasaran (4th ed.). yogyakarta: Andi. 